\title{
ECONOMICS
}

\section{THE UNITED STATES GOVERNMENT DEBT AND ITS INFLUENCE ON STABILITY OF THE WORLD FINANCIAL SYSTEM}

\author{
Ye. Kamshibayev ${ }^{1}$
}

DOI: http://doi.org/10.15350/L_26/8/09

\begin{abstract}
At the beginning of the 21st century the condition of a financial system of the USA and their international financial positions cause contradictory estimates of scientists and experts, politicians, and also a general population, both in the United States, and in other countries. This discrepancy is connected with speed and the radical nature of changes in the international economic positions of the USA which were comprehended adequately not at once.
\end{abstract}

Keywords: United States government debt, finance system, US dollar.

From a position of traditional representations it is possible to notice that at obvious economic superiority of the USA over other countries of the world in a financial position of this country there were considerable deviations from the accepted criteria of balance. Accepting as the fact world leadership of the USA in economic potential, achievements in the field of scientific and technical progress, to financial power and world influence, analysts watchfully expect the "sudden" and strong crisis shocks capable instantly everything to change [1].

Fears before possible crisis tendencies in the American financial system have certain reasons which follow from the processes of globalization changing shape of world economy. The USA possesses one of key roles in world trends.

The beginning of the 1980th years was noted by crisis of the international debt which captured big group of developing countries and demanded development in relation to them the new strategy of economic and financial assistance. In the same years there was a registration of the international financial market as the independent sphere having own potential of development and exerting strong impact on national monetary systems. The market of eurodollars which was considered as generation of deficiency of the balance of payments of the USA was a kernel of the international financial market. Around it the market of eurobonds, and also other assets expressed in foreign currencies in relation to the countries in which they took place and addressed began to be formed.

1Yermek Kamshibayev, Doctor of Economic Sciences, Full Professor of Economics, East Kazakhstan State University, Kazakhstan. 
The profound changes which happened in national economy in the 19701980th years meant emergence of new quality of world situation of the USA. Character of economic superiority of the United States over their partners in group of the developed countries changed. As one of the main centers of world economic development interferes with objective assessment of position of the United States the deficiency of trade balance of the country formed in 1971 which continuously grows. In the USA this deficiency long was considered as an annoying deviation which has to be corrected at the expense of more effective policy in the field of economy and foreign trade. At the beginning of the XXI century when deficiency of trade balance approached in size the cost of the American export, the speech about its full elimination doesn't go any more. But the problem of its reduction is considered as extremely important. It is considered that the modern extent of deficiency poses in themselves threat to stability of the American economy.

Serious fears are caused by high and various dependence of economy of the USA on inflow of the foreign capital. Inflow of the foreign capital is connected with deficiency of foreign trade and balance of the current operations, is considered as the extraordinary phenomenon. Many analysts consider this inflow a form of the growing external debt of the United States posing threat for financial and economic stability.

Not less serious danger is connected with revival at the beginning of the XXI century of deficiency of the state budget in large sizes and the growing public debt. These tendencies involve dependence on uninterrupted inflow of foreign investments into the American debt assets.

State of the economy of the USA as main center of world economic development creates the growing market for the American partners. For the last one and a half decades the economy of the United States acts as the main engine of world economic growth. During the 1990th - the beginning of the 2000th years neither the EU, nor Japan could make an alternative of the USA in this role [2].

Growth of the American economy became a long-term factor of world economic development. Owing to the big absolute sizes of economy of the USA each percent of its gain has powerful value and strongly influences economies of other countries via mechanisms of the international economic interaction. The United States act as the main center of world economic development which through numerous communications with other partners strongly influences the nature of development of their national economies.

Long-term character and the large extent of trade deficiency of the USA are caused by considerable structural shifts in the international division of labor which are caused by the fundamental reasons. Growth of import of the United States - the back of an asset of trade balance of many trade partners of the USA for whom sale of goods in the American market serves one of the main conditions of growth and development. To such countries the states of the EU, Japan, South Korea, China and other states treat with export orientation of economy. During economic recession of the beginning of the 2000th years in the USA not only import, but also export which growth at such moments was considered before as 
means of maintenance of business activity was reduced. Such rather new tendency is connected with globalization: cyclic falling of economic activity affects the whole groups of the countries now, the markets of trade partners of the United States are reduced. It interferes with growth of the American export, despite all efforts of the USA. Upon transition of the American economy to growth also export opportunities of the country in connection with increase in competitiveness of the American companies through scientific and technical progress increase. At the same time finds the expression in rapid growth of import the growing dependence of the USA on trade partners. In trade relations between the United States as the country leading in world economy and its partners put an important factor of world economic development. Now the strategy of work on the American market is actively used by China.

Radical change of a role of the USA in the international capital flow and strengthening of the American influence on the directions and the nature of the movement of financial resources in world economy became one of the main aspects of globalization. The main trade partners at the same time act as large investors in the American economy. Forcing out the American resources of work and the capital from one branches through the trade competition, they at the same time finance development of other branches and creation in them new jobs through investment of the capital into economy of the USA.

The international capital flow was strongly influenced from the USA throughout all second half of the XX century. Feature of a modern situation is that for the last three decades the United States, remaining the large exporter of the capital, were consistently transformed to his main world importer.

Influence of the United States on the international movement of portfolio investments is the most considerable. Superiority of economy and the stock market of the USA by the sizes, reliability and profitability, on a variety of financial instruments and high technology of operations - the main reason of the growing scales of foreign investment into the American financial assets. Inflow of foreign investments into the USA began to exceed their export in the 1980th years, but it reached the most considerable sizes in recent years what the following these tables confirm. They show that inflow of the foreign capital in the United States accepts more considerable sizes, showing ability of the American economy without serious consequences to accept and place the sums, huge to modern measures. Sharp growth of the direct investments which exceeded 320 billion dollars in 2000 showed what scope for such investments is capable to open rapid growth of the strongest economy in the world [3].

In the conditions of globalization of the USA alone can't cope with problems of instability of the world financial markets. The movement of world financial resources found the contradictory character. On the one hand, the majority of the countries of the world is involved in processes of their modulation through borders in search of effective assets today. On the other hand, massive movement of financial resources between the countries finds the powerful potential of destabilization, for mitigation or elimination of which joint international actions are required. 


\section{References}

[1] Vavilov A. Public debt: Lessons of crisis and principles of management. M.: Gorodets, 2003. 122 pages.

[2] Vavilov Yu. Ya. Public debt: Manual for higher education institutions. M.: Prospect publishing house, 2007. 256 pages.

[3] Beloglazova G. N. Finance and credit: Textbook. M.: The higher education, 2006. 575 pages. 